\title{
SHOPPER MARKETING STRATEGY IN FOOD RETAILING
}

\author{
Zoran Bogetićl, Dragan Stojković ${ }^{2}$,Siniša Miloševic ${ }^{3}$
}

\begin{abstract}
Summary
The leading role of retailers in food industry marketing channels significantly contributes to shopper marketing affirmation. Shopper marketing is a new marketing paradigm which focuses on the shopper and point-of-sale. Results of thorough literature review on shopper marketing have been presented in this paper. In addition, research methodology includes surveying 1000 shoppers in food retail stores in Belgrade area. The paper considers and analyzes the characteristics of urban food retail market shoppers, and based on the findings of the conducted research concludes that adaptation of shopper marketing strategies is necessary. Significant research finding is that shoppers' perceptions in food retail market require a profiled approach to retail store strategy adjustments, which includes shopper marketing programs and activities. The paper opens a number of questions regarding possible approaches to shopper marketing by crisscrossing the variables of retail formats, sex, and shoppers' income categories.
\end{abstract}

Keywords: shopper marketing, food retailing, shopper preferences, retail formats

JEL: $M 21, M 31, L 81, Q 13$

\section{Introduction}

Shopper marketing is a recent business concept (O’Leary, 2013) that announces a bright future of the new marketing approach focused on shoppers and also a relative deviating from the traditional consumer orientation. The new shopper marketing orientation additionally affirms the importance of the point-of-sale and related business activities, which is a kind of step forward with respect to the affirmed business concepts of trade marketing, customer relationship management (CRM), and product category management (Bogetić, Petković,

1 Zoran Bogetić PhD, Associate professor, University of Belgrade, Faculty of Economics, Kamenička Street no. 6, 11000 Belgrade, Republic of Serbia, Phone: +381 113021 163, E-mail: bogeticz@ekof.bg.ac.rs.

2 Dragan Stojković PhD, Assistant professor, University of Belgrade, Faculty of Economics, Kamenička Street no. 6, 11000 Belgrade, Republic of Serbia, Phone: +381 113021 131, E-mail: dstojkovic@ekof.bg.ac.rs.

3 Siniša Milošević, $\mathrm{PhD}$, Adviser, Commission for Protection of Competition, Savska Street no. 25, 11000 Belgrade, Republic of Serbia, Phone: +381 113811 931, E-mail: sinisa. milosevic3@gmail.com.

EP 2016 (63) 1 (189-204) 
2014). Currently, retailers undoubtedly dominate food industry marketing channels (Lovreta et al., 2013), and other participants simply adjust to them. Active efforts of suppliers are noticeable in development of partnership conceptions' (Gosselin, Bauwen, 2006), and all of this is in the function of increasing shoppers' enthusiasm (Coltman, 2007).

From the beginning of the $21^{\text {st }}$ century, the traditional focus on consumers and consumption, imposed by production and distributor (wholesale) companies, has been losing its importance. A more and more prevailing shopper marketing concept is being developed, including important strategic and organizational guidelines (Sorensen, 2009/a; Sorensen, 2009/b).

Having in mind the ever growing importance of shopper marketing, the question arises whether defining a uniform shopper marketing strategy can produce the desired results or is it, in fact, necessary to make certain adjustments depending on the needs and characteristics of the targeted group of shoppers. The subject of this research is directed to understanding of the needs and local characteristics of shoppers in a specific field of trade. The aim of this paper is to show, through understanding and analysis of local market needs and characteristics, whether adaptations of shopper marketing strategy are necessary or not.

Therefore the following statement is used as the starting hypothesis for this research:

The differences in shoppers' requirements at retail formats level impose the necessity of adaptable shopper marketing.

Retailers and suppliers must recognize the shopping patterns of different shopper segments, which are sometimes selected at the level of behavior variables such as shopping opportunity (Kotler et al., 2007; George, 2012). The shopping missions of different targeted shopper groups, as well as the way in which these missions would be actualized (place, time, expectations, stimuli, etc.), should be defined. Understanding the nature of a specific natural need and making shopping decisions in the targeted shopper segment becomes the main preoccupation of the retailers and suppliers that apply shopper marketing.

In the following text, main literature review findings on shopping marketing will be explained. In addition, research methodology, research results and its discussion will be presented.

\section{Shopper marketing strategy - logic and focal points}

The retail revolution has brought about changes in positions and relationships in marketing channels, emphasizing the importance of the point-of-sale marketing. Traditional approach to brand management makes no sense when capital and information are concentrated in retail, on the one hand, while there is an overflow of offers and proliferation of media, on the other. Above all, shoppers live ever faster and are less available to mass media, so the in-store contact with shoppers is crucial.

Recognizing different in-store shopping situations is the basis for development of advanced shopping experience, which is of use to both shoppers and also retailers and suppliers. Advanced shopping experience is certainly the objective of shopper marketing, regardless of whether regular or urgent purchases, that can more or less be planned, are concerned (Corrigan, 1997). 
The shopping mission, which shoppers actualize in a specific retail format, should determine the shopper marketing content (Alexander, 2008). For example, product package (Vranica, 2008), POS communication (Burke et al., 2009) and shopping convenience (Brett et al., 2012) should all be suited for the situation in which shoppers find themselves.

Developing a shopper marketing program appropriate for a specific store is a challenging creative task, which requires investing time and other resources. This business ideal in its own right of customized solutions for a specific store and its shoppers should contribute to more effective shopper marketing, including loyalty and shopping as a routine (Turano, 2012).

The needs of the defined retail shoppers are in focus, which is also pointed to by the following widely accepted definition: "Shopper Marketing is the use of insights-driven marketing and merchandising initiatives to satisfy the needs of targeted shoppers, enhance the shopping experience, and improve business results and brand equity for retailers and manufacturers" (Shopper Marketing Best Practices, 2010). There are various possible approaches to gathering the data on shoppers, including the following: loyalty programs, scanned data, online polls, in-store interviews, ethnographic research, focus on shopper groups, and shopper panels (Pincott, 2012).

The aim is to treat shoppers systematically in different shopping process phases and in an individualized manner (Alexander, 2015). Modern technology enables communication with shoppers at any place, inside and outside the store, and also before, during, and after shopping. All the stated above, among other things, significantly impacts the increase in POS activities' importance. The increase in the number of stimuli that shoppers are exposed to in shopping process is getting more and more obvious every day. In addition, shoppers are influenced at key points during the entire shopping process, whereby their behavior inside and outside the store is monitored in a balanced manner (Wyner, 2011). Shankar and his associates suggest that shoppers must be influencedlong before they enter the store, whereby they point to the conclusion about the importance of the sequence of steps which are applied to influence the shoppers (Shankar et al., 2011). In addition, consistent communication with shoppers, both inside and outside the store, is crucial for an effective shopper marketing program (Pincott, 2012; Kessler, 2011). Regarding this, Fam and his associates conclude that shopper marketing should consist of an integrated marketing program in the full sense of the word (Fam et al., 2011).

The perception of offered value is decisive with respect to shopper behavior and retail effect (Verhoef, 2007). In this context, a retailer develops a shopper marketing program adjusted to the entire offer and the selected shoppers of the store (Nitzberg, 2012). Thus, for example, retailers should attend to the shoppers' pickiness with respect to assortment in the environment of a wide selection of opportunities, that is, in the environment of a fierce competition and rich market offer (Levav, Zhu, 2009).

The total in-store communication, including discount offers, should be balanced according to the targeted shoppers' profile. With respect to the focus on more affluent shoppers, for example, the in-store communication should be adjusted with the emphasis on quality and prestige, for which the shopper is willing to pay (Baker et al., 2002). Starting from the 
above statements on shopper marketing, the research into shoppers' perception regarding the factors which are decisive when the shoppers make their choice of food retail store has been conducted and all this is done for the purpose of testing the accepted starting hypothesis. These factors, at the same time, represent the focus points for defining of shopper marketing strategy in retail. The research includes the following factors: price, sales personnel, parking, working hours, loyalty programs, and private labels share.

\section{Research methodology}

In the research, we used the method of direct surveying of shoppers who shopped in mainly food retail stores at the territory of Belgrade. In this area a total of 1,778 retail stores were identified by 31 March 2014 included, with total selling space of over 250,000m² (Milošević, 2015), which means that average selling space of individual store was somewhat over 140 $\mathrm{m}^{2}$. Individual retail stores are statistical elements, and the set of all individual retail stores in Belgrade's city core are population.

The research included 1,000 respondents. Surveying of shoppers was done on the field by method of personal interview, that is, the shoppers were surveyed immediately after their shopping and the questionnaire was designed in advance. One of the survey's objectives was to, based on the shoppers' attitudes and habits, identify potentially possible shopper marketing strategies in food retail, and specifically for individual retail formats at the territory of Belgrade's city core. Based on the existing experience with respect to analyzing a specific retail store from shoppers' perspective, it is necessary to survey 50 or more respondentsshoppers. This means that this research required a sample of 20 retail stores. Also, we have compared the ratings obtained by means of simple random sampling technique and by means of stratified random sampling technique on the samples of the same size selected from the population comprising all retail stores in Belgrade's city core.

The results of comparison, as expected, show that ratings' precision significantly increases when stratification is applied. Besides the increased precision of ratings, the sample scope is also significantly increased. We have managed to obtain a representative sample of the retail stores where respondents were surveyed.

The entire research was designed to follow the established scientific hypothesis. A five-point Likert scale was used in the questionnaire, so the respondents were able to rate, on a scale from one to five (one being the lowest, and five being the highest rating), the importance of individual factors which were decisive in their selection of a particular store to shop in. The shoppers were surveyed after they had completed their shopping in the retail stores selected for the stratified sample according to the previously described methodology. The sample consisted of four strata which included different retail formats. The results of the survey are presented in the continuation of this text. 


\section{Results and discussion of the research results}

When all the respondents' answers are observed, store's location is the most important factor when shoppers are selecting a retail store. The overview of the ratings of all factors is presented in the following Table.

Table 1. Ratings of the shopping factors at the level of all the surveyed respondents

\begin{tabular}{|c|l|c|}
\hline $\begin{array}{c}\text { Rating } \\
\text { position }\end{array}$ & Factor & $\begin{array}{c}\text { Average rating } \\
\text { (1-5) }\end{array}$ \\
\hline 2 & Favorable prices & 4.327 \\
\hline 1 & Location (distance) from retail store & 4.528 \\
\hline 3 & Product assortment & 4.318 \\
\hline 6 & Pleasant ambience & 4.089 \\
\hline 4 & Sales personnel & 4.163 \\
\hline 7 & Parking space & 3.202 \\
\hline 5 & Store's working hours & 4.162 \\
\hline 9 & Loyalty program (cards) & 2.757 \\
\hline 8 & Private labels & 3.167 \\
\hline
\end{tabular}

Source: The authors'calculations.

The summarized overview, however, gives only an average image. In order to make decisions related to shopper marketing strategy, it is necessary to observe the focus points through different shopper profiles. Shopper profiles may be defined in various ways. For the purpose of this research, we analyzed shoppers' profiles established according to the following criteria: format of retail store where shoppers shop, sex, and shoppers' income.

\section{Shoppers 'preferences according to retail store format}

The analysis of shoppers' profiles, defined based on the place where they shop, is founded on categorizing the shoppers according to the format of the retail store where they did their shopping. The formats are defined according to Trade Formats Rules (Official Gazette of the Republic of Serbia, 2011), according to which a store of up to $200 \mathrm{~m}^{2}$ selling space is categorized as mini-market, from 200 to $400 \mathrm{~m}^{2}$ as convenience market store, from 400 to 2,000 $\mathrm{m}^{2}$ as supermarket, and over 2,000 $\mathrm{m}^{2}$ as hypermarket. Besides the selling space size, other characteristics were also taken into consideration. Bearing in mind the previously described methodology and sampling method, each of the four observed formats has 250 responses.

Table 2. The responses of the shoppers who shopped in the stores with selling space of less than $200 \mathrm{~m}^{2}$

\begin{tabular}{|c|l|c|}
\hline Rating position & Factor & $\begin{array}{c}\text { Average rating } \\
\text { (1-5) }\end{array}$ \\
\hline 5 & Favorable prices & 4.184 \\
\hline 1 & Location (distance) from retail store & 4.872 \\
\hline
\end{tabular}




\begin{tabular}{|c|l|c|}
\hline Rating position & Factor & $\begin{array}{c}\text { Average rating } \\
\text { (1-5) }\end{array}$ \\
\hline 4 & Product assortment & 4.320 \\
\hline 3 & Pleasant ambience & 4.360 \\
\hline 2 & Sales personnel & 4.480 \\
\hline 7 & Parking space & 2.776 \\
\hline 5 & Store's working hours & 4.184 \\
\hline 9 & Loyalty program (cards) & 2.280 \\
\hline 8 & Private labels & 2.576 \\
\hline
\end{tabular}

Source: The authors'calculations.

From the previous table it is obvious that store's location is the most important factor from shoppers' perspective when choosing a retail store with less than $200 \mathrm{~m}^{2}$ of selling space, that is, the most important thing for shoppers who buy in such stores is how close the store is to their homes. Sales personnel is second in importance, pleasant ambience is third, and so on.

Table 3. The responses of the shoppers who shopped in the stores with selling space from 200 to $400 \mathrm{~m}^{2}$

\begin{tabular}{|c|l|c|}
\hline Rating position & Factor & $\begin{array}{c}\text { Average rating } \\
\text { (1-5) }\end{array}$ \\
\hline 4 & Favorable prices & 4.024 \\
\hline 1 & Location (distance) from retail store & 4.532 \\
\hline 2 & Product assortment & 4.216 \\
\hline 6 & Pleasant ambience & 3.732 \\
\hline 5 & Sales personnel & 4.000 \\
\hline 9 & Parking space & 2.588 \\
\hline 3 & Store's working hours & 4.128 \\
\hline 7 & Loyalty program (cards) & 2.948 \\
\hline 8 & Private labels & 2.780 \\
\hline
\end{tabular}

Source: The authors' calculations.

From the previous table it is obvious that store's location is the most important factor from shoppers' perspective when choosing a retail store with selling floor space from 200 to 400 $\mathrm{m}^{2}$, that is, the most important thing for shoppers who buy in such stores is how close the store is to their homes. Product assortment is second in importance, working hours are third, and so on. 
Table 4. The responses of the shoppers who shopped in the stores with selling floor space from 400 to $2,000 \mathrm{~m}^{2}$

\begin{tabular}{|c|l|c|}
\hline Rating position & Factor & $\begin{array}{c}\text { Average rating } \\
\text { (1-5) }\end{array}$ \\
\hline 1 & Favorable prices & 4.552 \\
\hline 2 & Location (distance) from retail store & 4.452 \\
\hline 3 & Product assortment & 4.332 \\
\hline 4 & Pleasant ambience & 4.276 \\
\hline 5 & Sales personnel & 4.268 \\
\hline 8 & Parking space & 3.356 \\
\hline 6 & Store's working hours & 4.148 \\
\hline 9 & Loyalty program (cards) & 2.836 \\
\hline 7 & Private labels & 3.876 \\
\hline
\end{tabular}

Source: The authors'calculations.

From the previous table it is obvious that prices are the most important factor from shoppers' perspective when choosing a retail store with selling space from 400 to $2,000 \mathrm{~m}^{2}$, that is, favorable prices are the most important thing for shoppers who buy in such stores. Location of the store, that is, how far the store is from shoppers' homes is second in importance, product assortment is third, and so on.

Table 5. The responses of the shoppers who shopped in the stores with selling space larger than $2,000 \mathrm{~m}^{2}$

\begin{tabular}{|c|l|c|}
\hline Rating position & Factor & $\begin{array}{c}\text { Average rating } \\
\text { (1-5) }\end{array}$ \\
\hline 1 & Favorable prices & 4.548 \\
\hline 3 & Location (distance) from retail store & 4.256 \\
\hline 2 & Product assortment & 4.404 \\
\hline 6 & Pleasant ambience & 3.988 \\
\hline 7 & Sales personnel & 3.904 \\
\hline 5 & Parking space & 4.088 \\
\hline 4 & Store's working hours & 4.188 \\
\hline 9 & Loyalty program (cards) & 2.964 \\
\hline 8 & Private labels & 3.436 \\
\hline
\end{tabular}

Source: The authors' calculations.

From the previous table it is obvious that prices are the most important factor from shoppers' perspective when choosing a retail store with selling floor space larger than $2,000 \mathrm{~m}^{2}$, that is, favorable prices are the most important thing for shoppers who buy in such stores. Product assortment is second in importance, location is third, and so on.

Based on the previous analysis, it is noticeable that the importance of individual factors from shoppers' perspective differs depending on formats of the observed retail stores. Therefore, 
it may be concluded that different shopper marketing strategies need to be formulated for different retail formats.

\section{Shoppers 'preferences according to sex}

Of the total number of respondents, $43 \%$ were males, and $57 \%$ were females.

Table 6. The responses of male shoppers

\begin{tabular}{|c|l|c|}
\hline Rating position & Factor & Average rating (1-5) \\
\hline 2 & Favorable prices & 4.362 \\
\hline 1 & Location (distance) from retail store & 4.498 \\
\hline 3 & Product assortment & 4.293 \\
\hline 6 & Pleasant ambience & 4.047 \\
\hline 4 & Sales personnel & 4.174 \\
\hline 7 & Parking space & 3.364 \\
\hline 5 & Store's working hours & 4.171 \\
\hline 9 & Loyalty program (cards) & 2.458 \\
\hline 8 & Private labels & 3.089 \\
\hline
\end{tabular}

Source: The authors' calculations.

Table 7. The responses of female shoppers

\begin{tabular}{|c|l|c|}
\hline Rating position & Factor & Average rating (1-5) \\
\hline 3 & Favorable prices & 4.301 \\
\hline 1 & Location (distance) from retail store & 4.551 \\
\hline 2 & Product assortment & 4.336 \\
\hline 6 & Pleasant ambience & 4.120 \\
\hline 4 & Sales personnel & 4.155 \\
\hline 8 & Parking space & 3.082 \\
\hline 4 & Store's working hours & 4.155 \\
\hline 9 & Loyalty program (cards) & 2.979 \\
\hline 7 & Private labels & 3.225 \\
\hline
\end{tabular}

Source: The authors'calculations.

With regard to profiling of shoppers according to their sex, both male and female shoppers state that location is first in importance. However, further ratings show that favorable prices are second in importance for male, while product assortment comes second in importance for female shoppers. Product assortment comes second in importance for male, while favorable prices are second in importance for female shoppers. Sales personnel and store's working hours are fourth and fifth in importance respectively for women, while these two factors are both fourth in importance for men. Both sexes rate pleasant ambience as sixth in importance. Parking space comes seventh for men, while private labels are seventh in importance for women. Private labels are eight in importance for men, while for women parking space holds that position. Both sexes rated loyalty programs as ninth in importance. 
Based on the results presented, it is noticeable that the attitudes of shoppers profiled according to sex and retail store formats are very different. In the function of testing the research's starting hypothesis, we have also considered the shoppers' preferences according to their income.

\section{Shoppers' preferences according to their income}

Of the total number of respondents, $42 \%$ had above average household income and $43 \%$ had below average household income, while $15 \%$ of respondents answered that they did not know or refused to answer the household income related question.

Table 8. The responses of shoppers with above average household income

\begin{tabular}{|c|l|c|}
\hline Rating position & Factor & Average rating (1-5) \\
\hline 2 & Favorable prices & 4.330 \\
\hline 1 & Location (distance) from retail store & 4.490 \\
\hline 3 & Product assortment & 4.316 \\
\hline 5 & Pleasant ambience & 4.081 \\
\hline 5 & Sales personnel & 4.081 \\
\hline 7 & Parking space & 3.543 \\
\hline 4 & Store's working hours & 4.199 \\
\hline 9 & Loyalty program (cards) & 2.775 \\
\hline 8 & Private labels & 3.383 \\
\hline
\end{tabular}

Source: The authors' calculations.

Table 9. The responses of shoppers with below average household income

\begin{tabular}{|c|l|c|}
\hline Rating position & Factor & Average rating (1-5) \\
\hline 2 & Favorable prices & 4.324 \\
\hline 1 & Location (distance) from retail store & 4.526 \\
\hline 3 & Product assortment & 4.343 \\
\hline 5 & Pleasant ambience & 4.154 \\
\hline 5 & Sales personnel & 4.207 \\
\hline 7 & Parking space & 2.959 \\
\hline 4 & Store's working hours & 4.136 \\
\hline 9 & Loyalty program (cards) & 2.814 \\
\hline 8 & Private labels & 3.145 \\
\hline
\end{tabular}

Source: The authors' calculations

With respect to profiling shoppers according to their households' income, we may conclude that retail store location is crucial for both observed groups. However, differences are more than obvious with respect to rating of other factors.

Lower income shoppers rate product assortment as second in importance, while higher income shoppers rate favorable price as second in importance. Based on this, we may conclude that higher income shoppers dedicate more attention to product prices than lower 
income shoppers do. The explanation for this illogical situation could be that the respondents provided socially desirable answers in the survey, that is, that the lower income respondents did not want to admit that the price was most important to them. Also, lower income shoppers are less mobile (they do not own cars, retired people shop only in local store, and so on), so they shop in only one store regardless of the prices.

Higher income shoppers rate product assortment, while lower income shoppers rate favorable price as third in importance. Working hours are rated as fourth in importance by higher income shoppers, while lower income shoppers rate sales personnel fourth in importance. Both shopper categories rate pleasant ambience as fifth in importance, but higher income shoppers also rate sales personnel the same, while lower income shoppers rate working hours as sixth in importance. Higher income shoppers rate parking space, while lower income shoppers rate private labels as seventh in importance. Higher income shoppers rate private labels, while lower income shoppers rate parking space as eight in importance. Both categories of shoppers rate loyalty program as the least important. In order to obtain a more detailed insight into the shoppers' preferences according to sex, it is necessary to analyze the profiling of shoppers according to their income with respect to different retail formats. The summary of this analysis is shown in the following Figure.

Figure 1. The results of responses structures according to shoppers' income and retail formats

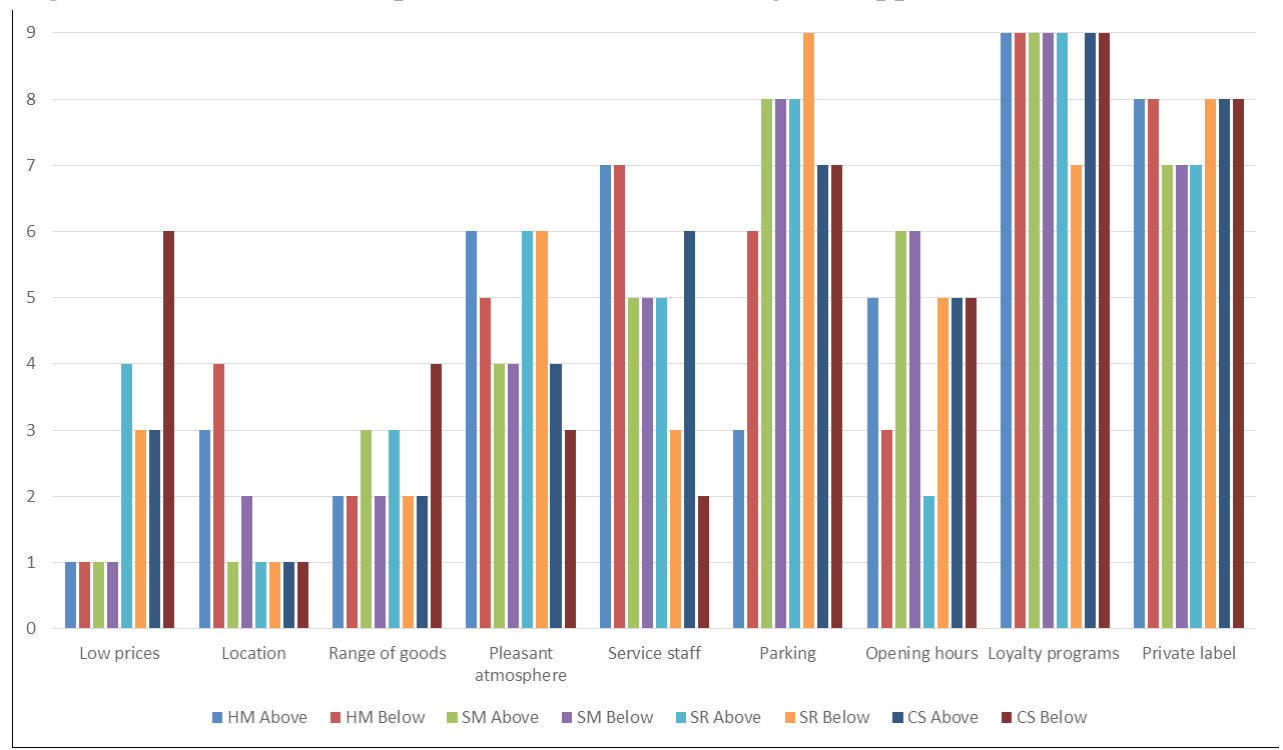

HM (hypermarket)-formats over $2000 \mathrm{~m}^{2}$; SM (supermarket)-formats 400-2000 m²; SR (convenience market store)-formats $200-400 \mathrm{~m}^{2}$; CS (mini-market)-formats smaller than $200 \mathrm{~m}^{2}$

Source: The authors' calculation.

When the factor of favorable prices is concerned for retail formats larger than 2,000 $\mathrm{m}^{2}$ and for formats of 400-2,000 $\mathrm{m}^{2}$, both shopper categories rate it as first in importance. For retail formats of 200-400 $\mathrm{m}^{2}$, higher income shoppers rate it as fourth, while lower income shoppers rate it as fifth in importance. However, in store formats smaller than $200 \mathrm{~m}^{2}$, higher 
income shoppers rate the factor of favorable price as third, while lower income shoppers rate is as sixth in importance.

Location factor is rated lowest by shoppers in retail formats larger than 2,000 $\mathrm{m}^{2}$ - higher income shoppers rate it as third, while lower income shoppers rate it as fourth in importance. Higher income shoppers rate this factor as first in importance in retail formats of 400-2,000 $\mathrm{m}^{2}$, while lower income shoppers in this format rate it second. Location is the most important factor, rated as first in importance, by shoppers in formats of 400-2,000 $\mathrm{m}^{2}$ and also by the ones in retail formats smaller than $200 \mathrm{~m}^{2}$, regardless of their incomes.

Product assortment as a factor in selecting a retail store for shopping is rated as second in importance by both shopper categories in retail formats larger than $2,000 \mathrm{~m}^{2}$. In retail formats of 400-2,000 $\mathrm{m}^{2}$ higher income shoppers rate this factor as third, while lower income shoppers rate it as second in importance. The situation is reversed in formats of $200-400 \mathrm{~m}^{2}$ - higher income shoppers rate product assortment as third, while lower income shoppers rate it as second in importance. In store formats smaller than $200 \mathrm{~m}^{2}$ higher income shoppers rate this factor second, while lower income shoppers rate it fourth in importance.

Based on the results presented, it is noticeable that the attitudes of shoppers profiled according to income and retail store formats are very different. The analyzed results show that the shoppers' perception regarding selection of a retail store for shopping is significantly determined by the retail format type of the store. In addition, it is noticeable that there are also significant differences in format level with respect to shoppers' sex and also with respect to shoppers' household income. Thus, for example, in retail store formats smaller than 200 $\mathrm{m}^{2}$ men have shown different attitudes about certain number of factors than women have. In addition, shoppers with higher than average household income show different attitudes with respect to certain factors than shoppers with lower than average household income. The same applies with respect to the remaining three formats. Each format shows certain differences in ratings of individual factors.

The research results confirm the starting hypothesis, that is, they point to the conclusion that shopper marketing programs should be adjusted to specific shoppers' requirements at retail store level. For the purpose of achieving better sales figures on food products they have in their assortment, suppliers and retailers must take specific characteristics of Belgrade market shoppers into account.

In smaller stores with selling floor space of up to $200 \mathrm{~m}^{2}$, it is only logical that location should be the primary factor for selection of the store for shopping, but the fact that sales personnel and pleasant ambience are rated very high - higher than prices or assortment - is also a very important piece of information. This insight offers elements for development of shopper marketing strategy by the retailers who focus on smaller format retails stores. The fact that private labels and loyalty programs are rated relatively low in importance by the respondents is also an important implication. However, it should be pointed out that both of these factors are still insufficiently developed in Belgrade market, and they are also rapidly gaining in importance, so they should not be neglected. 


\section{Conclusion and directions for further research}

The conclusion of the research is that the importance of individual factors from shoppers' perspective differs depending on the observed retail store formats. Shoppers have different shopping missions in different retail formats. Our research points out that the most important factor for shoppers in smaller stores are location and sales personnel. They require comfortable shopping. On the other hand, shoppers are more rational when they shop in large formats. Therefore, shopper marketing activities are focused on price attractiveness and wide assortment.

We may conclude that different shopper marketing strategies should be formulated for different retail store formats, whereby the research's starting hypothesis is confirmed. This research findings are completely consistent with focus on point of sale marketing investments efficiency which characterize shopper marketing.

With respect profiling of shoppers according to sex, both men and women rate store location as first in importance. However, in further ratings, favorable prices are most important for men, while product assortment is most important for women. Based on the presented results, it is noticeable that the attitudes of shoppers profiled according to sex vary significantly. Therefore, the option implementing different shopper market strategies based on the targeted shopper groups profiled according to sex should be considered in more detail in future researches.

When shoppers' profiles according to their household income are observed, we may conclude that location of the retail store plays a key role in both higher and lower income shoppers. However, some differences have been observed in ratings of other factors. This is the reason enough to conduct further researches into shoppers segmented in this way, for the purpose of developing a model for shopper marketing strategy adaptation.

Besides the analysis of the received responses summarized with respect to sex and household income, the paper also presents the analysis of the stated shopper segments for each retail store format type. The research results show that shopper groups segmented according to sex, on the one hand, and according to household income on the other, display different preferences with respect to the importance of individual factors which impact the selection of store, and that these preferences also differ with respect to each retail store format type.

We conclude that retailers and suppliers must recognize the shopping patterns of different shopper segments at store level. Store characteristics, such as product assortment and display, indeed impact the shoppers' perception on the values offered in a particular store. Generally speaking, the ambiance in the store plays an important role when shoppers make decisions about the store to shop in.

Based on the conducted research, we may conclude that shoppers' perceptions in food retail market require a profiled approach to retail store strategy adjustments, which includes shopper marketing programs and activities. This is, undoubtedly, a strenuous task which requires adequate knowledge and resources, whereby the effect of strategic differentiation and positioning of retail offer at the level of locally recognized and respected demand is achieved. 
Shopper marketing strategy in predominantly food retail stores is relatively new and still insufficiently explored field, especially in Serbia. It would be very interesting to research into the potential of shopper marketing strategy in rural areas. Research into shopper marketing strategy according to different food products categories is also a very challenging field. In addition, it would be interesting to explore some specific types of food retail categories, such as, organic food products or products that claim to bring nutritional or health benefits. A comparative analysis of shopper marketing strategies in several countries, for example, the Balkan Region countries or the countries of former Yugoslavia, could also be important for both theorists and practitioners. This is even more true due to the fact that shopper marketing concept is relatively young and insufficiently developed, especially at the level of local practices and capabilities.

\section{References}

1. Alexander, A. (2008): Study sorts out shopper behaviour, Drug Store News, November 17, 2008 , p.73.

2. Alexander, A. (2015): Survey: U.S. consumers desire personalized retail experience, control over personal data, available at: httpwww.drugstorenews.comarticlesurvey-usconsumers-desire-personalized-retail-experience-control-over-personal-data, October 2, 2015.

3. Baker, J., Parasuraman, A., Grewal, D., Voss, G. (2002):The Influence of Multiple Store Environment Cues on Perceived Merchandise Value and Store Patronage Intentions, Journal of Marketing, Vol. 66, No. 2, pp. 120-141.

4. Bogetić, Z., Petković, G. (2014):Kako pripremiti trgovinsko poduzeće za shopper marketing?, in N. Knego, S. Renko, B. Knežević (Eds.), Perspektive trgovine 2014: Ljudi, tehnologija, znanje, pp. 140-154, Zagreb: Faculty of Economics and Business, University of Zagreb.

5. Brett, A.S.M. (2012):A Stranger's Touch: Effects of Accidental Interpersonal Touch on Consumer Evaluations and Shopping Time, Journal of Consumer Research, Vol. 39, No. 1, pp. 174-184.

6. Burke, R. R. (2009):Behavioral Effects of Digital Signage, Journal of Advertising Research, Vol. 49, No. 2, pp. 180-185.

7. Coltman, T. (2007):Why build a customer relationship management capability?, The Journal of Strategic Information Systems, Vol. 16, No. 3, pp. 301-320.

8. Corrigan, P. (1997): The Sociology of Consumption, SAGE Publications, London.

9. Fam, K. S., Merrilees, B., Richard, E.J., Joysa, L., Li Y., and Krisjanous(2011):Instore marketing: a strategic perspective,Asia Pacific Journal of Marketing and Logistics, Vol. 23. No. 2, pp. 165-176.

10. George, S. (2012):Occasion Based Promotional Strategies of Consumer Durable Segment in Kerala, International Journal of Academic Research in Business and Social Sciences, Vol. 2, No. 6, pp. 431-442.

11. Gosselin, D., and Bauwen, G. (2006):Strategic Account Management: Customer Value Creation Through Customer Alignment,Journal of Business \& Industrial Marketing, Vol. 21, No. 6, pp. 376-385.

EP 2016 (63) 1 (189-204) 
12. Kessler, C. (2004):Branding in store - Marketing in the 21st century, Journal of Brand Management, Vol. 11, No.4, pp. 261-264.

13. Kotler, P., Keller, L.K., Koshy, A., Jha, M. (2007): Marketing Management. Pearson Education, Delhi.

14. Levav, J. Zhu, J.R. (2009.):Seeking Freedom through Variety, Journal of Consumer Research,Vol. 36, No. 4, pp. 600-610.

15. Lovreta, S., Končar, J., Petković, G. (2013):Kanali marketinga, CID, Faculty of Economics, University of Belgrade, Belgrade.

16. Milošević, S. (2015): Model rešavanja sukoba korporativne i javne politike u lokaciji trgovinskih objekata, Doctoral Dissertation, Faculty of Economics, University of Belgrade.

17. Mintzberg H., Ahlstrand B., Lampel J. (1998):Starategy Safary- A Guided Tourthrough The Wilds of Strategic Management, The Free Press, New York.

18. Nitzberg, M. (2012): Putting the shopper in your shopper marketing strategy, in: Shopper Marketing: How to Increase Purchase Decisions at the Point of Sale, Stahlberg, M., and Maila,V. editors, 2nd ed., Kogan Page, London, pp. 181-201.

19. O'Leary, N. (2013): Shopper Marketing Is Going Mainstream-Retail is the center of gravit, Adweek, May 19, available at: http://www.adweek.com/news/advertising-branding/ shopper-marketing-going-mainstream-149630, November 5, 2015.

20. Petrović, Lj. (2007):Teorija uzoraka i planiranje eksperimenata, Belgrade: CID,Faculty of Economics, University of Belgrade.

21. Pincott, G. (2012): Point of view on shopper marketing, in: Shopper Marketing: How to Increase Purchase Decisions at the Point of Sale, Stahlberg, M., and Maila,V.editors, 2nd ed., Kogan Page, London, pp. 9-12.

22. Shankar, V., Inman, J.J., Mantala, M., Kelley, E., Rizley, R.(2011):Innovations in Shopper Marketing: Current Insightes and Future Research Issues, Journal of Retailing, Vol.87, Supplement 1, pp. 29-42.

23. Shopper Marketing Best Practices: A Collaborative Model for Retailers and Manufacturers (2010): In-Store Institute \& The Partnering Group: A Report from the Retail Commission on Shopper Marketing, p. 5.

24. Silveira, P., Marreiros, K. (2014):Shopper Marketing: A Literature Review, International Review of Management and Marketing, Vol. 4, No. 1, pp. 90-97.

25. Sorensen, H. (2009/a): Inside the Mind of the Shopper- The Science of Retailing, Prentice Hall, Upper Saddle River, New Jersey.

26. Sorensen, H. (2009/b):The in-store audience, Journal of Advertising Research, 49 (2), pp. 176-179.

27. Official Gazette of the Republic of Serbia no. 47/11, Trade Formats Rules (2011).

28. Turano, M.M.A. (2012): Tailing your shoppers-retailing for the future, in Stahlberg, M., Maila, V. (Eds.): Shopper Marketing: How to Increase Purchase Decisions at the Point of Sale, 2nd ed., pp. 87-92, London: Kogan Page.

29. Turley, L.W., Chebat, J.C. (2002):Linking retail strategy, atmospheric design and shopping behaviour, Journal of Marketing Management, Vol.18, No.1-2, pp.125-144.

30. Verhoef, P. A., Neslin, S. A., Vroomen, B. (2007):Multichannel customer 
management: Understanding the research-shopper phenomenon, International Journal of Research in Marketing,Vol. 24, No. 2, pp. 129-148.

31. Vranica, S. (2008):Team Unilever-The ultimate shopper insight is that sales and marketing need to think as one, The Wall Street Journal, 4/10/08, available at: http:// hubmagazine.com/html/2008/may_jun/unilever.html, September 20, 2015.

32. Wyner, G. (2011): Shopper Marketing, Journal of Marketing management, Vol. 20, No. 1, p. 44. 


\title{
STRATEGIJA KUPOVNOG MARKETINGA U PREHRAMBENOJ MALOPRODAJI
}

\section{Zoran Bogetič́, Dragan Stojkovič ${ }^{5}$, Siniša Miloševićc ${ }^{6}$}

\begin{abstract}
Rezime
Vodeća uloga maloprodaje u prehrambenim kanalima marketinga daje značajan doprinos afirmaciji kupovnog marketinga-nove marketinške paradigme u čijem je fokusu kupac $i$ mesto prodaje. Rezultati temeljne analize naučne literature koja se bavi kupovnim marketingom su prezentovani u radu. Metodologija istraživanja uključuje anketiranje 1000 kupaca prehrambenih maloprodajnih objekata na području Beograda. U radu se sagledavaju i analiziraju karakteristike kupaca urbanog tržišta prehrambene maloprodaje i u skladu sa nalazima realizovanog istraživanja izvodi zaključak o neohodnoj adaptaciji strategije kupovnog marketinga. Značajan rezultat istraživanja je da percepcije kupaca na prehrambenom maloprodajnom tržištu zahtevaju profilisani pristup prilagođavanju strategije maloprodajnog objekta koji uključuje programe i aktivnosti kupovnog marketinga. Rad otvara brojna pitanja mogućih pristupa kupovnog marketinga ukrštajući varijable maloprodajnih formata, pola $i$ visine primanja kupaca.
\end{abstract}

Ključne reči: kupovni marketing, prehrambena maloprodaja, preferencije kupaca, maloprodajni formati.

4 Vanredni profesor, dr Zoran Bogetić Univerzitet u Beogradu, Ekonomski fakultet, Ulica Kamenička br. 6, 11000 Beograd, Republika Srbija, Telefon: +381 113021 163, E-mail: bogeticz@ekof.bg.ac.rs.

5 Docent, dr Dragan Stojković Univerzitet u Beogradu, Ekonomski fakultet, Ulica Kamenička br. 6, 11000 Beograd, Republika Srbija, Telefon: +381 113021 131, E-mail: dstojkovic@, ekof.bg.ac.rs.

6 Samostalni savetnik, dr Siniša Milošević, Sektoru za ispitivanje koncentracije u Komisiji za zaštitu konkurencije, Ulica Savska br. 25, 11000 Beograd, Republika Srbija, Telefon: +381 113811 931, E-mail: sinisa.milosevic3@gmail.com. 